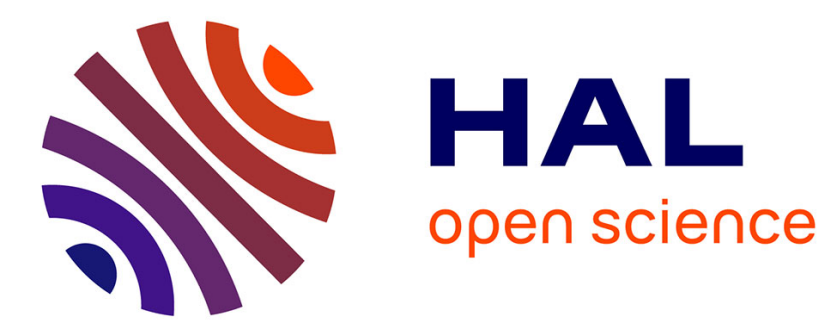

\title{
Effects of spacing and genetic entry on radial growth and ring density development in Scots pine (Pinus sylvestris L.)
}

Gort-Oromi, Mehtätalo, Peltola, Zubizarreta-Gerendiain, Pulkkinen, Venäläinen

\section{To cite this version:}

Gort-Oromi, Mehtätalo, Peltola, Zubizarreta-Gerendiain, Pulkkinen, et al.. Effects of spacing and genetic entry on radial growth and ring density development in Scots pine (Pinus sylvestris L.). Annals of Forest Science, 2011, 68 (7), pp.1233-1243. 10.1007/s13595-011-0117-8 . hal-00930686

\section{HAL Id: hal-00930686 https://hal.science/hal-00930686}

Submitted on 1 Jan 2011

HAL is a multi-disciplinary open access archive for the deposit and dissemination of scientific research documents, whether they are published or not. The documents may come from teaching and research institutions in France or abroad, or from public or private research centers.
L'archive ouverte pluridisciplinaire HAL, est destinée au dépôt et à la diffusion de documents scientifiques de niveau recherche, publiés ou non, émanant des établissements d'enseignement et de recherche français ou étrangers, des laboratoires publics ou privés. 


\title{
Effects of spacing and genetic entry on radial growth and ring density development in Scots pine (Pinus sylvestris L.)
}

\author{
Jaume Gort-Oromi • Lauri Mehtätalo • Heli Peltola • \\ Ane Zubizarreta-Gerendiain • Pertti Pulkkinen • \\ Ari Venäläinen
}

Received: 24 January 2011 / Accepted: 14 July 2011 /Published online: 4 August 2011

(C) INRA and Springer Science+Business Media B.V. 2011

\begin{abstract}
- Introduction The objective of this work was to study how spacing and genetic entry and/or origin group affect radial growth (ring width and cumulative diameter development) and ring density from pith to bark in Scots pine (Pinus sylvestris L.) and in what sense their annual variability could be explained by the climatic variables. The spacing trial was located in central Finland, with current stand density range of 2,000-4,000 trees per hectare. All the six genetic entries had Kanerva pine (plus tree S1101) as a father tree, whereas the mother tree represented Finnish plus trees from southern, central and northern Finland.

- Methods In the early phase of the stand development, no significant differences $(p<0.05)$ were found for mean ring
\end{abstract}

\section{Handling Editor: Luc Pâques}

J. Gort-Oromi $(\bowtie) \cdot$ L. Mehtätalo $\cdot$ H. Peltola $\cdot$

A. Zubizarreta-Gerendiain

School of Forest Sciences, University of Eastern Finland,

P.O. Box 111, 80101 Joensuu, Finland

e-mail: jaume.gort@uef.fi

P. Pulkkinen

Haapastensyrjä Breeding Station,

Finnish Forest Research Institute,

Karkkilantie 247,

12600 Läyliäinen, Finland

A. Venäläinen

Finnish Meteorological Institute,

00101 Helsinki, Finland

Present Address:

A. Zubizarreta-Gerendiain

Forest Research Centre, School of Agriculture, UTL,

Tapada da Ajuda,

1349-017 Lisbon, Portugal width (RW), cumulative diameter (Dt1) and mean ring density (RD) development between different spacing and/or origin groups (southern, central and northern ones).

- Results Both cambial age and spacing affected RW and $\mathrm{RD}$ development from pith to bark. In addition, RD development was affected by the origin group (OG), unlike RW. The annual radial growth also decreased slightly earlier and much faster in the narrowest spacing.

- Conclusion The annual variation in RW could not be explained by the climatic factors considered (e.g. temperature sum during the growing season or June and/or July mean temperature). However, the mean temperature for current June and the temperature sum during the current growing season partly explained the annual variation in RD $(p<0.05)$.

Keywords Radial growth · Ring density · Spacing · Genetic entry. Climatic variability

\section{Introduction}

In Scandinavia, Scots pine (Pinus sylvestris L.) is an important source of raw material not only for sawn timber but also for the pulp and paper industry. Long-term breeding programmes for Scots pine have usually considered stem volume growth and sawn timber quality as selection traits of primary importance, whereas properties such as wood density has been taken as a secondary trait. However, wood density in Scots pine is important, for example, for strength properties of sawn timber and pulp yield (Ståhl 1988). In Scots pine, like in other coniferous species, wood density is moderately to highly inherited and shows moderate genetic age-age correlations between 
juvenile and mature wood. This makes tree selection successful even at a reasonably young age (Zobel and van Buijtenen 1989; Hannrup and Ekberg 1998; Hannrup et al. 2000; Fries and Eriksson 2006).

In Scots pine, wood density increases from pith to bark most rapidly during the juvenile phase, i.e. within first 5-15 rings from the pith (Persson et al. 1995). Concurrently, in some cases, an increase in radial growth has been found to decrease at least slightly the overall wood density (e.g. Persson et al. 1995; Wilhelmsson et al. 2002; Peltola et al. 2007). However, during the juvenile phase, ring density and ring width do not necessarily correlate negatively in Scots pine (Hannrup et al. 2000). In addition, a non-significant or a weak positive relationship between them has also been observed (Mörling 2002).

In the early phase of the stand development, the radial growth of tree stem can be affected by the initial spacing and pre-commercial thinnings (e.g. Persson et al. 1995; Peltola et al. 2007). Usually in Finland, Scots pine is planted with an approximate density of 2,000 trees per hectare, with additional regeneration material being obtained by natural regeneration. Alternatively, seeding or natural regeneration can be used. Regardless of the regeneration method, the stand density is usually decreased down to 2,000-2,500 trees per hectare in the tending of the seedling stand with an average tree height of $5-8 \mathrm{~m}$.

According to many previous studies, the climatic factors, especially the temperature in the growing season, affect the radial growth of trees in northern Europe (e.g. Henttonen 1984; Miina 2000; Salminen and Jalkanen 2004; Salminen et al. 2009). The effect of precipitation is usually considered to be of minor importance for Scots pine growing under Finnish conditions, as the evaporative demand is low in relation to precipitation (Mielikäinen et al. 1996; Miina 2000). Contradictorily, Henttonen (1984) suggested that precipitation sum during May to July of the previous summer affected tree ring growth in Scots pine. In central Finland, the radial growth of Scots pine lasts from mid-May to mid-August (Kanninen et al. 1982; Peltola et al. 2002; Henttonen et al. 2009) and about $80 \%$ to $90 \%$ of it happens during June and July, and the remaining 5\% and $9 \%$ in May and August, respectively (Henttonen et al. 2009). For Scots pine, late wood formation (width) seems to be affected by the prevailing temperature between July and August (e.g. Mikola 1950; Leikola 1969; Saikku 1975; Kellomäki 1979; Miina 2000), while early wood formation (width) correlates positively with May and June temperature (Antonova and Stasova 1993). Additionally, young trees are more likely to respond to the current climatic conditions, unlike older trees (e.g. Mikola 1950).
Different genetic entries may show different growth responses to the annual variability of climatic conditions. Similarly, differences may be observed under varying spacing in this respect. However, few studies exist in Finland on the simultaneous effects of genetic entry, spacing and annual variation in climatic conditions (e.g. temperature and precipitation) on radial growth and ring density development from pith to bark in Scots pine. In the above context, the objective of this work was to study how the spacing and genetic entry/origin group affect radial growth (ring width and cumulative diameter development) and ring density from pith to bark in Scots pine and in what sense their annual variability could be explained by the climatic variation.

\section{Material and methods}

\subsection{Experimental data}

The material used in this study was harvested in autumn 2008 from a Scots pine spacing trial established in 1987 at Siilinjärvi (trial 1216/01) in central Finland. According to the data obtained from the meteorological station at Kuopio $\left(63^{\circ} 06^{\prime} \mathrm{N}, 27^{\circ} 41^{\prime} \mathrm{E}, 85 \mathrm{~m}\right.$ above sea level), the average annual temperature ranged from $+2.8^{\circ} \mathrm{C}$ to $+5.0^{\circ} \mathrm{C}$ for the period 1991-2006. The corresponding range for the average January (the coldest month) temperature was $-15.3^{\circ} \mathrm{C}$ to $-4.1^{\circ} \mathrm{C}$, while the range for the average June and July temperature was $+11.1^{\circ} \mathrm{C}$ to $+18.4^{\circ} \mathrm{C}$ and $+14.9^{\circ} \mathrm{C}$ to $+20.8^{\circ} \mathrm{C}$, respectively (Fig. 1). The annual precipitation sum ranged from 492 to $793 \mathrm{~mm}$ (Fig. 1), while for the growing season (between May and September), it ranged from 179 to $468 \mathrm{~mm}$ for the same period. Averages for monthly mean temperatures and precipitation sums for our experimental site during the period of 1991-2006, as well as corresponding time series for monthly mean temperatures during the growing season are shown in Fig. 1.

The spacing trial is located on old agricultural soil (fertile site) and consists of three different spacing treatments with initial stand densities of 2,000, 4,000 and 8,000-8,200 trees per hectare. In autumn 2000, the widest spacing was left unmanaged (referred later as spacing 1), medium spacing was thinned to 2,000-2,500 trees per hectare (spacing 2) and the narrowest spacing to 4,000 trees per hectare (spacing 3). Furthermore, regardless of spacing, pruning of lower branch whorls was done in order to increase the quality of the lower part of the stem.

In autumn 2008, we selected six genetic entries, all of them having Kanerva pine (plus tree S1101) as a father tree, whereas the mother trees represented Finnish plus trees with a relatively wide geographical range from northern to 

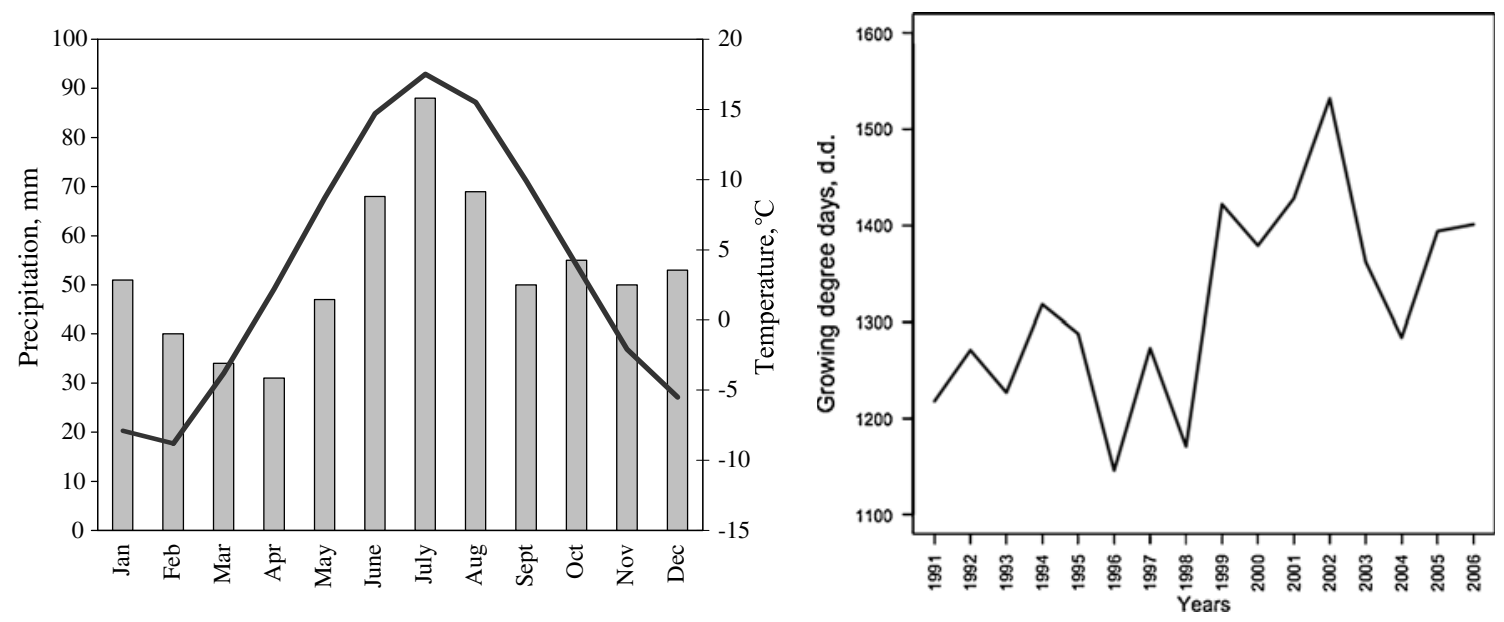

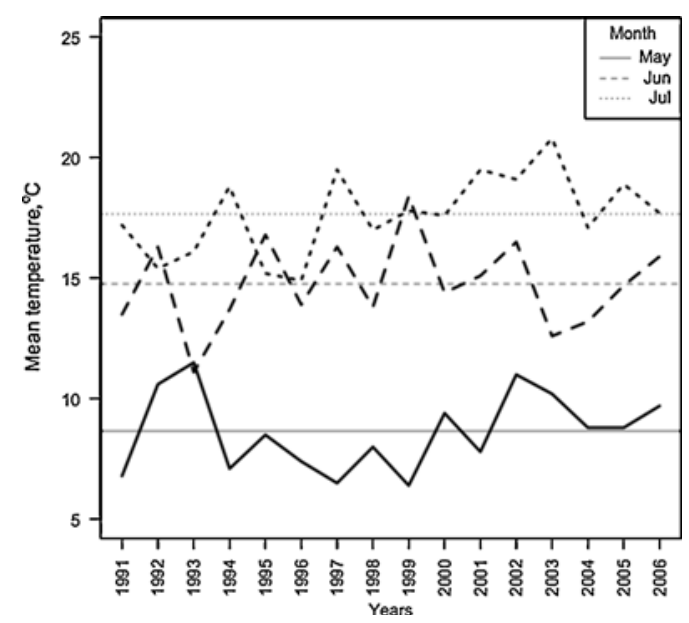

Fig. 1 Climatic variation at Kuopio meteorological station $\left(63^{\circ} 06^{\prime} \mathrm{N}\right.$, $27^{\circ} 41^{\prime} \mathrm{E}, 85 \mathrm{~m}$ above sea level). Mean monthly temperature $\left({ }^{\circ} \mathrm{C}\right.$, line $)$ and mean monthly precipitation sum ( $\mathrm{mm}$, bars) calculated for the period 1991-2006 (top left), temperature sum d.d. (i.e. growing degree

southern Finland (Table 1). Five sample trees per genetic entry and spacing were randomly harvested, giving a total of 90 sample trees. We measured tree height and stem diameter at $1.3 \mathrm{~m}$ for each sample tree and took sample discs at $1 \mathrm{~m}$ height from each sample tree for further analyses of ring width and ring density development from pith to bark.

Table 1 Origin group (OG) of the controlled crossings between S1101 Kanerva pine (father) from Punkaharju (South Finland) and mother trees from different geographic origin

\begin{tabular}{lrl}
\hline OG & Crossing type & Site origin of mother trees \\
\hline 1 North & $\mathrm{N} 1924 \times \mathrm{S} 1101$ & Taivalkoski \\
1 North & $\mathrm{N} 334 \times \mathrm{S} 1101$ & Kemijärvi \\
2 Central & $\mathrm{C} 205 \times \mathrm{S} 1101$ & Multia \\
2 Central & $\mathrm{C} 214 \mathrm{~B} \times \mathrm{S} 1101$ & Äänekoski \\
3 South & $\mathrm{S} 2582 \times \mathrm{S} 1101$ & Kuru \\
3 South & $\mathrm{S} 104 \times \mathrm{S} 1101$ & Tammela \\
\hline
\end{tabular}

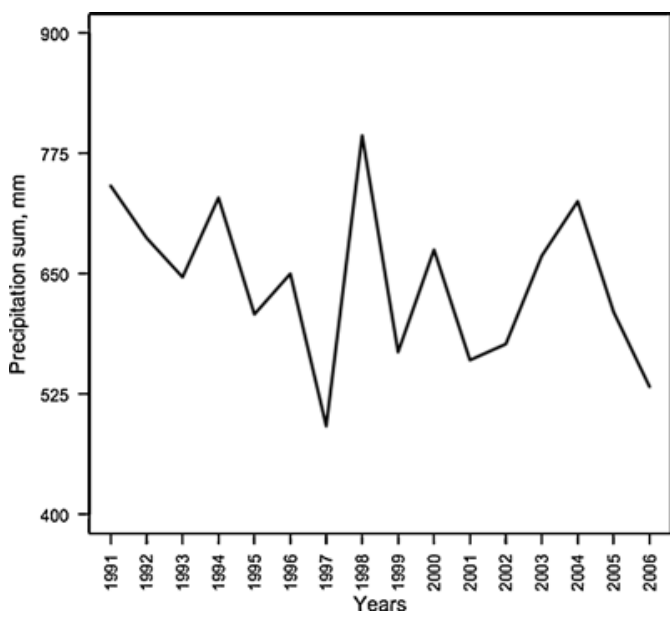

days, d.d., considering daily mean temperatures $>+5^{\circ} \mathrm{C}$ ) for the period 1991-2006 (top right), mean temperature with 16 year average line for May to July (bottom left), and annual precipitation sum (bottom right)

\subsection{Laboratory analyses}

For ring width and ring density analyses, ring density profiles from pith to bark were measured for each sample tree, using the ITRAX X-ray microdensitometer (Cox Analytical Systems, Göteborg, Sweden) at the University of Eastern Finland, School of Forest Sciences. For this purpose, a radial segment from pith to bark in the north direction (5 $\mathrm{mm}$ axially and tangentially) was cut from each disc and stabilised for a few weeks to have a moisture content of $12 \%$ (air dry). Thereafter, the samples were scanned using the ITRAX (with standard X-ray intensity $30 \mathrm{kV}, 35 \mathrm{~mA}$ and exposure time of $20 \mathrm{~ms}$ ), recording $\mathrm{X}$ ray images with a geometrical resolution of 40 measurements per millimetre (see Peltola et al. 2007). With the Density software program (Bergsten et al. 2001) and excel macros, the X-ray images were further analysed to determine intra-ring density profiles for each wood specimen, and concurrently ring widths and ring densities for 
each ring from pith to bark, excluding one ring nearest pith and two outermost rings near the bark.

\subsection{Statistical data analyses}

The average intra-ring properties, ring width $(\mathrm{RW}, \mathrm{mm})$ and ring density $\left(\mathrm{RD}, \mathrm{g} / \mathrm{cm}^{3}\right)$, of the two genetic entries within each origin group (Table 1) did not differ statistically significantly (one-way ANOVA) regardless of spacing. Therefore, differences for RW and RD over the years were studied only between different spacing as an average and between different origin groups spacing by spacing (Table 2). The homogeneity of the variance (Levene's test of equality of error variances) and normality of the data (Shapiro-Wilk test, Shapiro and Wilk 1965) were also tested for each variable.

In this study, our main interest was to study the effects of spacing, origin group and calendar year on ring width (RW) and ring density (RD). For that propose, a mixed model for $\mathrm{RW}$ and RD data was fitted in order to explore which factors (e.g. origin group, spacing and climatic variables) could explain the annual variability in the ring width and ring density. In this work, the cambial age is a nuisance trend, which needs to be modelled away to better recognise the effects of different variables.

Because all the trees were planted at the same time (and were equally old), it was not easy to separate the effect of a given calendar year from the age trend. However, we assumed that the growth up to $1 \mathrm{~m}$ height is largely affected by external factors, such as vegetation competition, dam-

Table 2 Mean and standard deviation of ring width (RW), ring density (RD) and cumulative diameter growth (Dt1) for each spacing and origin group $(\mathrm{OG})$ within spacing

\begin{tabular}{llll}
\hline & $\begin{array}{l}\text { RW, mm } \\
\text { Mean } \pm \mathrm{SD}\end{array}$ & $\begin{array}{l}\mathrm{RD}, \mathrm{g} / \mathrm{cm}^{3} \\
\text { Mean } \pm \mathrm{SD}\end{array}$ & $\begin{array}{l}\mathrm{Dt1}, \mathrm{mm} \\
\text { Mean } \pm \mathrm{SD}\end{array}$ \\
\hline Spacing 1 & & & \\
OG 1 & $3.55 \pm 1.5$ & $0.394 \pm 0.05$ & $64.18 \pm 42.36$ \\
OG 2 & $3.63 \pm 1.5$ & $0.381 \pm 0.05$ & $67.48 \pm 41.06$ \\
OG 3 & $3.43 \pm 1.5$ & $0.369 \pm 0.05$ & $64.94 \pm 40.45$ \\
All OG & $3.56 \pm 1.5$ & $0.381 \pm 0.05$ & $66.04 \pm 41.03$ \\
Spacing 2 & & & \\
OG 1 & $3.48 \pm 1.3$ & $0.388 \pm 0.04$ & $60.54 \pm 38.31$ \\
OG 2 & $3.58 \pm 1.4$ & $0.398 \pm 0.06$ & $64.70 \pm 39.70$ \\
OG 3 & $3.26 \pm 1.4$ & $0.378 \pm 0.05$ & $64.42 \pm 36.99$ \\
All OG & $3.45 \pm 1.4$ & $0.388 \pm 0.05$ & $63.43 \pm 38.21$ \\
Spacing 3 & & & \\
OG 1 & $2.94 \pm 1.6$ & $0.387 \pm 0.06$ & $59.44 \pm 35.12$ \\
OG 2 & $2.62 \pm 1.1$ & $0.393 \pm 0.05$ & $53.79 \pm 29.23$ \\
OG 3 & $2.88 \pm 1.4$ & $0.382 \pm 0.06$ & $57.76 \pm 32.35$ \\
All OG & $2.82 \pm 1.4$ & $0.388 \pm 0.06$ & $57.49 \pm 32.02$ \\
\hline
\end{tabular}

ages or small scale variation on the site, whereas the growth trend after reaching that height was assumed to be more strongly age-driven. That is why we used the cambial age as the predictor for the age trend. However, because cambial age varied in a given calendar year depending on sample tree (maximum variation was 5 years), we could separate the effect of age trend from that of random calendar year.

The age trend was modelled using a restricted cubic spline regression (Harrell 2001). The spline is a flexible, smooth curve that can be used for removing trends without making strict mathematical assumptions on the shape of the trend. The flexibility is controlled by the number of knots $t_{j}$ $(j=1, \ldots, k$, where $k$ is the total number of knots), which are placed within the range of cambial age. The age trend was modelled as spacing-specific. This yielded the following age trend for spacing $s$ :

$A_{s i t}=\beta_{0}+\beta_{1} X_{1}+\beta_{2} X_{2}+\ldots+\beta_{k-1} X_{k-1}$

where $X_{1}$ is the cambial age of tree $i$ at year $t$, and the other terms are the following functions of it and knots $t_{j}$ (see Harrell 2001)

$$
\begin{aligned}
X_{j+1}= & \left(X_{1}-t_{j-}\right)^{3}+-\left(X_{1}-t_{k-1}\right)^{3} \\
& +\left(t_{k}-t_{j}\right) /\left(t_{k}-t_{k-1}\right)+\left(X_{1}-t_{k}\right)^{3} \\
& +\left(t_{k-1}-t_{j}\right) /\left(t_{k}-t_{k-1}\right)
\end{aligned}
$$

For RD, we used four knots $t_{j}$ (at the 5th, 35th, 65th and 90th percentiles of the cambial age) and for RW seven knots $t_{j}$ (at the 2.5th, 18.33th, 34.17th, 50th, 65.83th, 81.67th and 97.5th percentiles of the cambial age), respectively.

The origin group was included as a dummy variable as it was assumed to always have an equal effect. Furthermore, random tree and calendar year effects were included in the model to take into account the effect of within-tree and within-year variability, respectively. The modelling of random effects took into account the specific hierarchical structure of the data, making the statistical testing of the models more reliable. In addition, it made possible to extract the year effects for each calendar year to explore the effect of climatic variables on the annual variability of the response. The obtained final full model for observed RW or RD for tree $i$, in spacing $s$, in a given year $t$, consists of the following components:

$R_{s i t}=A_{s i t}+O G_{i}+a_{t}+b_{i}+e_{i t}$

where $R_{\text {sit }}$ is the observed response (RW or RD) for tree $i$, in spacing $s$, at year $t, A_{s i t}$ is the trend related to the cambial age of the tree with spacing $s, O G_{i}$ is the fixed effect of the origin group, $a_{t}$ is the random effect related to calendar 
year, $b_{i}$ is the random tree effect and $e_{i t}$ is the unexplained residual variation.

This model was used for two purposes: first, to test the statistical significance of the fixed spacing and origin group effects on the ring width and ring density development from pith to bark. Secondly, the model was used to predict the random year effects in order to study their correlation with the climatic variables. Testing the significance of the fixed effects was done by fitting the full model (with all the fixed effects) and a restricted model (without some of the fixed effects such as genetic entry) and comparing them using the likelihood ratio test (see e.g. Pinheiro and Bates 2000). In this test, the null hypothesis is that the restricted model satisfactorily models the response and the alternative hypothesis is that the full model is significantly better. Latter one means that the fixed effect significantly explains the variation of the response. For these comparisons, the models were fitted by the method of maximum likelihood (see e.g. Pinheiro and Bates 2000). Once the final models (one for RW and one for RD) were found, their parameters were re-estimated using restricted maximum likelihood method to extract (practically) unbiased estimates of the random year effects. Then, the correlation between year effects and the selected climatic variables for the current and previous growing seasons were explored. The climatic variables considered were average monthly temperatures from October (previous year) to September (current year), monthly precipitation sum over the same period and temperature sum (i.e. sum of temperatures over $+5^{\circ} \mathrm{C}$ ) during the current growing period for years of 1991-2006 (i.e. May-September, see e.g. Peltola et al. 2002). All the statistical test were considered significant at $p<0.05$ level.
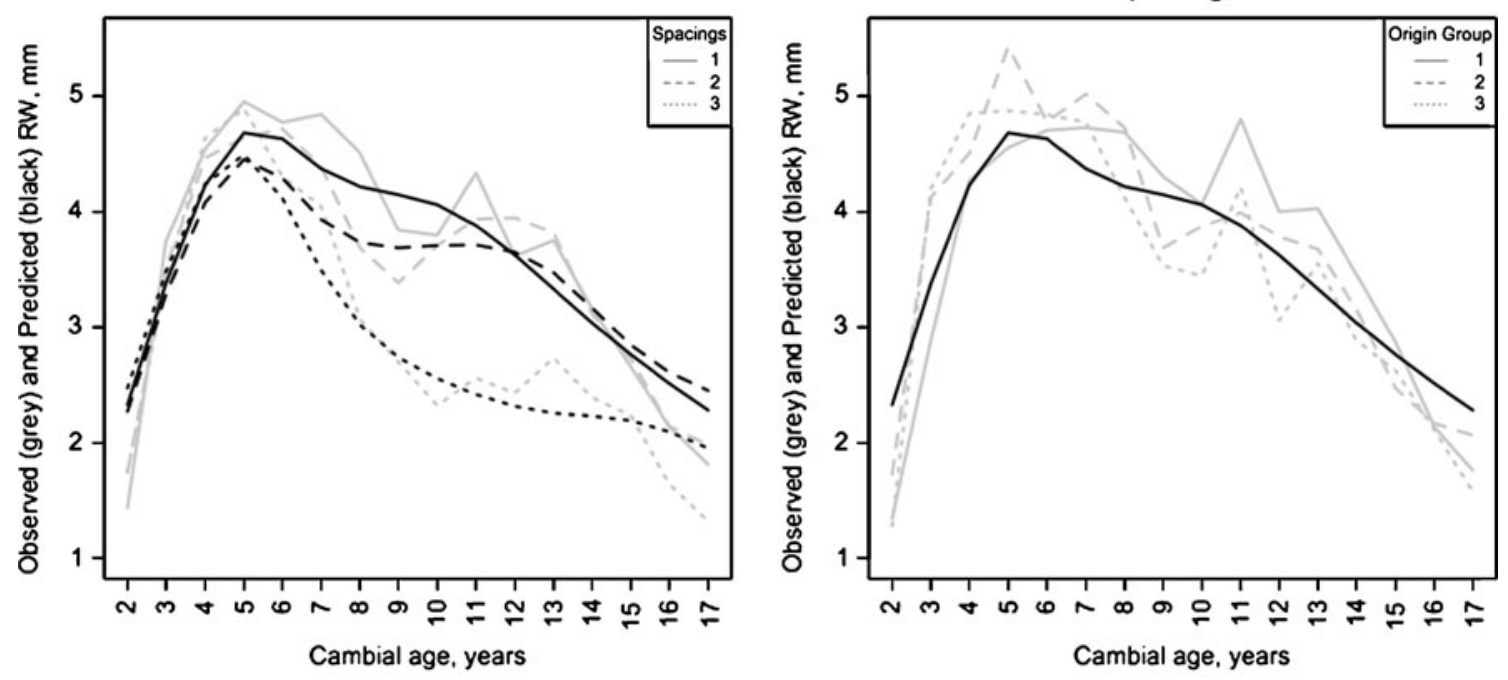

Spacing 2
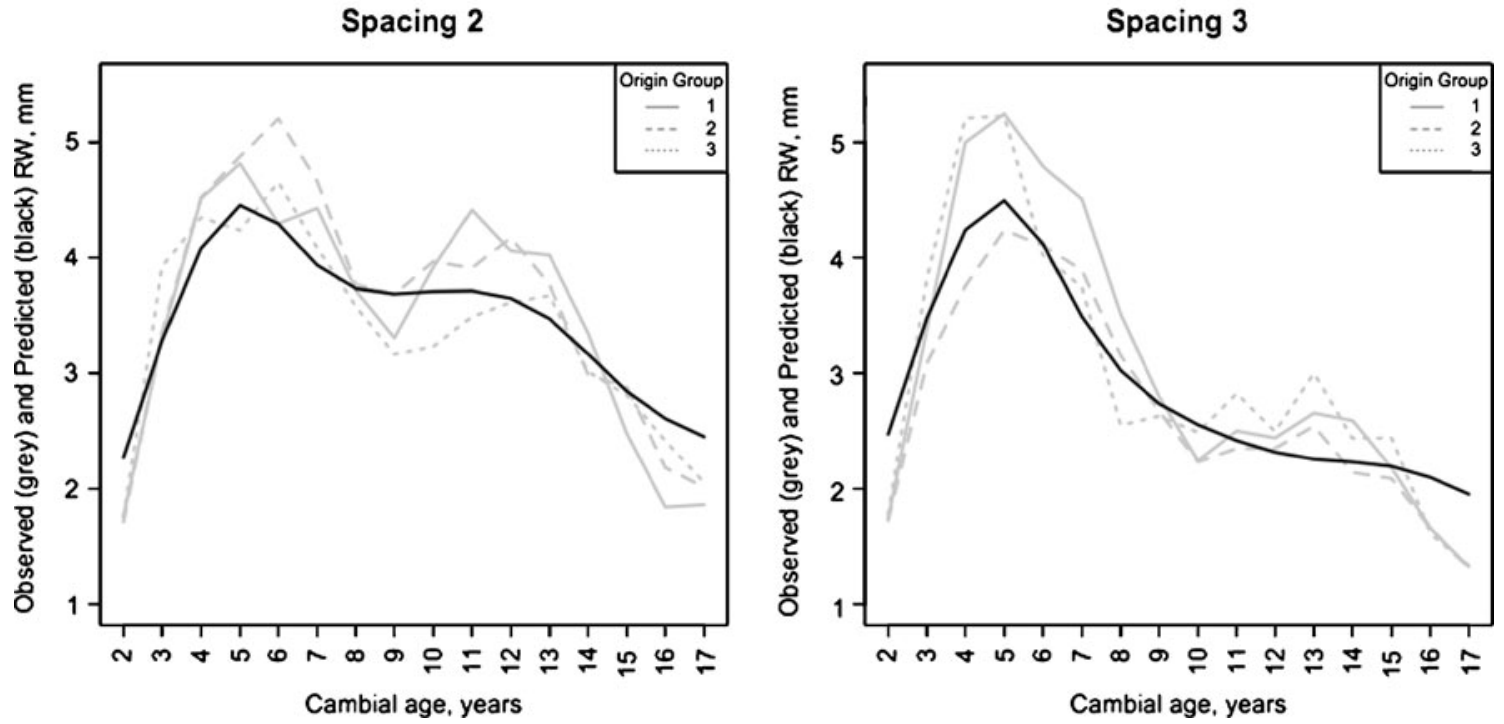

Fig. 2 Mean ring width (RW, mm) development from pith to bark in each spacing as an average over all origin groups (from 1 to 3, north to south) and for each origin group spacing by spacing (from 1 to 3, widest to narrowest). Grey lines represent observed data and black lines predicted values 


\section{Results}

3.1 Development of ring width, cumulative diameter growth and ring density

No statistically significant differences are found for mean ring width (RW) between origin groups (OG), regardless of spacing (Fig. 2) for cambial ages between 2 and 17 years old (i.e. corresponding wood formation in 1992-2006). But regarding spacing, mean RW is lower for the narrowest spacing 3 (current stand density of 4,000 trees per hectare) compared to spacing 1 and 2 (with current stand density of 2,000-2,500 trees per hectare) (Table 2). On the other hand, there is an increase in ring width after the pre-commercial thinning in spacing 2 and 3 in the year 2000 (cambial ages between 7 and 11) and the effect is the largest, on average, in spacing 2. The decrease in RW is also evident over time, regardless of spacing and/or origin group, but it starts 2 years earlier in the narrowest spacing 3 (Fig. 2). In the year 2002 (cambial ages between 9 and 13), a peak in the mean RW can be observed, regardless of spacing and origin group, opposite to the generally decreasing trend.

No clear differences exist for the cumulative diameter growth (Dt1) at different cambial ages when comparing spacing as an average over origin groups until cambial age 11 (Fig. 3 top left). Thereafter, the differences are statistically significant $(p<0.05)$ between spacing 3 and spacing 1 and 2, respectively. However, no statistically significant differences exist for the Dt1 between different OG regardless of spacing until cambial age 17 , but thereafter, the differences become significant $(p<0.05)$.
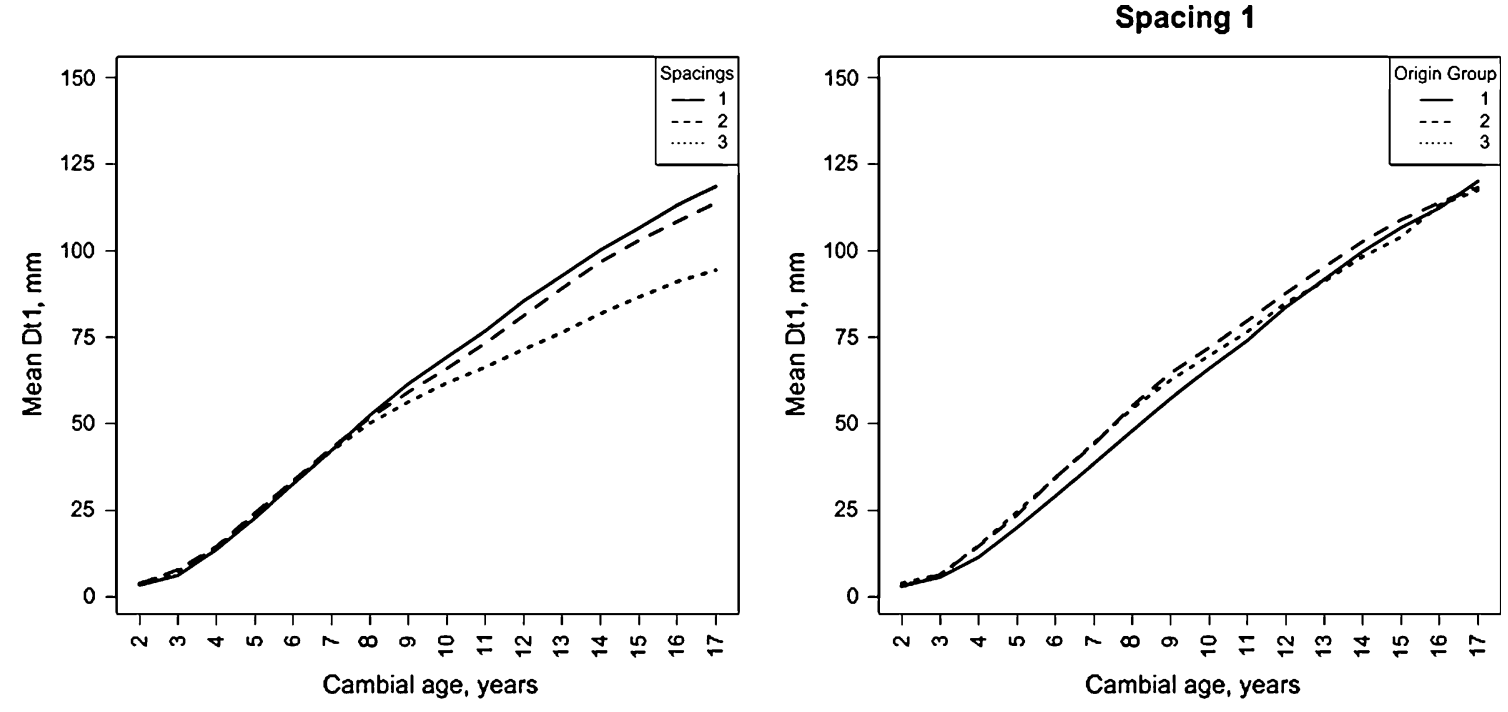

Spacing 2

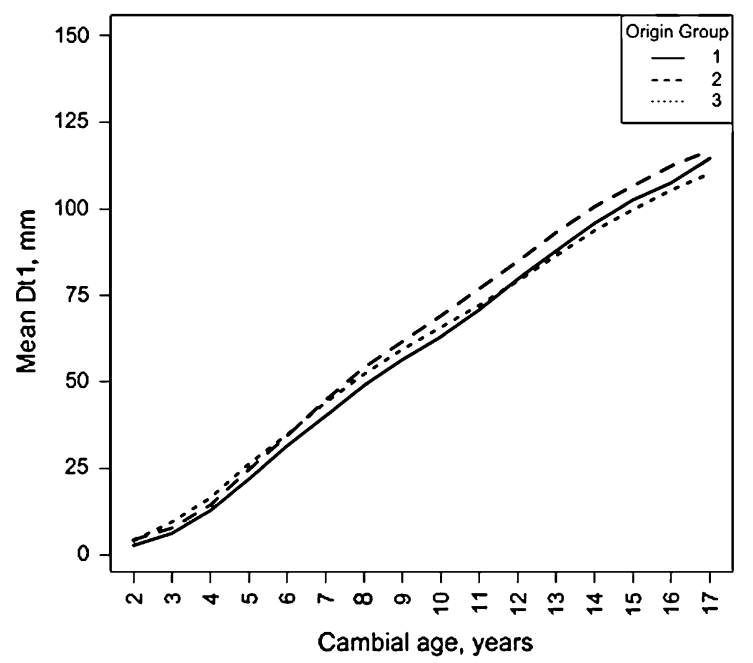

Spacing 3

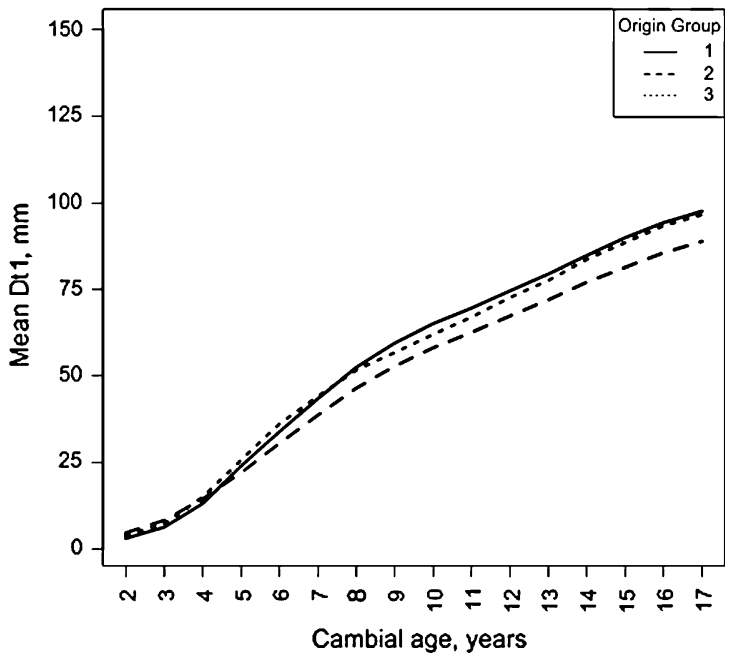

Fig. 3 Mean cumulative diameter growth (Dt1, mm) development for trees at different cambial ages for each spacing as an average for all origin groups (from 1 to 3 , north to south) and for each origin group spacing by spacing (from 1 to 3 , widest to narrowest) 
Similar to the mean RW, no statistically significant differences are found for the mean RD development from pith to bark over different OG regardless of spacing. For different spacing treatments, statistically significant differences are found between origin groups, but no clear pattern on those differences could be extracted. However, in spacing 1, the mean $\mathrm{RD}$ is, on average, lower $(p<0.05)$ for OG 3 compared to OGs 1 and 2 for cambial ages 2, 3, 8 and 9. Furthermore, OG 1 has a higher average RD than the other OGs until the last 4 years (Cambial age 14-17) in spacing 1 . Whereas, in spacing 2 and 3 the corresponding ranking between OGs varies depending on the year considered. Similar to the mean $\mathrm{RW}$, for cambial age 13, the mean RD, showed a peak regardless of spacing and origin group. This is expected to be related to the higher average temperature and temperature sum during the growing periods in 2000-2002 compared to corresponding averages over the whole period of 1991-2006 considered (see temperature sums in growing period of 2000 and 2002, Fig. 1).
3.2 Factors explaining annual development of ring width and ring density

The annual RW development from pith to bark is best explained by the linear mixed model with the following explanatory variables: age trend, spacing treatment, the interaction between spacing and age trend, and random "Tree" and "Year" effects (Table 3). The annual RD development from pith to bark is best explained by the origin group in addition to the same explanatory variables used in the RW model (Table 3). Figures 2 and 4 show the predicted RW and RD, respectively, with the linear mixed models versus the measured data.

The models for RW and RD include random effects for tree and year, which explain part of the variability for RW and RD (Table 3). As climatic factors may partly explain the year effect variability (Fig. 5), the correlation between random year effect and climatic variables was also studied (Fig. 6). However, it was found that the monthly precipi-

Table 3 Linear mixed model variables and parameters for ring width (RW) and ring density (RD) models

\begin{tabular}{|c|c|c|c|c|c|c|}
\hline \multirow[t]{2}{*}{ Fixed effects } & \multicolumn{3}{|l|}{ RW model } & \multicolumn{3}{|l|}{ RD model } \\
\hline & Estimate & Std. error & $t$ Value & Estimate & Std. error & $t$ Value \\
\hline (Intercept) & 0.1421 & 0.4491 & 0.3160 & 0.4113 & 0.0144 & 28.4960 \\
\hline Spacing2 & 0.0172 & 0.4388 & 0.0390 & 0.0052 & 0.0100 & 0.5180 \\
\hline Spacing3 & 0.2085 & 0.4430 & 0.4710 & -0.0523 & 0.0101 & -5.2010 \\
\hline Cambialage & 1.0938 & 0.1156 & 9.4640 & -0.0069 & 0.0017 & -3.9290 \\
\hline Component 1 & -0.0336 & 0.0051 & -6.6450 & 0.0001 & 0.0000 & 6.3640 \\
\hline Component 2 & 0.0993 & 0.0205 & 4.8450 & - & - & - \\
\hline Component 3 & -0.0822 & 0.0256 & -3.2140 & - & - & - \\
\hline Component 4 & 0.0227 & 0.0205 & 1.1040 & - & - & - \\
\hline Component 5 & -0.0031 & 0.0249 & -0.1250 & - & - & - \\
\hline Spacing2:Cambialage & -0.0367 & 0.1277 & -0.2870 & 0.0004 & 0.0012 & 0.3040 \\
\hline Spacing3:Cambialage & -0.0328 & 0.1287 & -0.2550 & 0.0075 & 0.0012 & 6.3620 \\
\hline Spacing2:c1 & -0.0023 & 0.0059 & -0.3880 & 0.0000 & 0.0000 & -0.2630 \\
\hline Spacing3:c1 & -0.0086 & 0.0059 & -1.4490 & 0.0000 & 0.0000 & -3.5890 \\
\hline Spacing2:c2 & 0.0108 & 0.0243 & 0.4460 & - & - & - \\
\hline Spacing3:c2 & 0.0272 & 0.0243 & 1.1210 & - & - & - \\
\hline Spacing2:c3 & -0.0067 & 0.0304 & -0.2200 & - & - & - \\
\hline Spacing $3: c 3$ & -0.0141 & 0.0303 & -0.4640 & - & - & - \\
\hline Spacing2:c4 & -0.0161 & 0.0244 & -0.6620 & - & - & - \\
\hline Spacing3:c4 & -0.0105 & 0.0242 & -0.4340 & - & - & - \\
\hline Spacing2:c5 & 0.0353 & 0.0296 & 1.1910 & - & - & - \\
\hline Spacing3:c5 & -0.0061 & 0.0293 & -0.2070 & - & - & - \\
\hline OG 2 & - & - & - & 0.0005 & 0.0069 & 0.0690 \\
\hline OG 3 & - & - & - & -0.0140 & 0.0069 & -2.0220 \\
\hline Random effects & Variance & Std. Deviation & Variance & Std. Deviation & & \\
\hline Tree & 0.3395 & 0.5827 & 0.00065 & 0.02547 & & \\
\hline Year & 0.1763 & 0.4198 & 0.00037 & 0.01918 & & \\
\hline Residual & 0.5370 & 0.7328 & 0.00107 & 0.03271 & & \\
\hline
\end{tabular}


tation sum and mean monthly temperatures from previous October to current August and the temperature sum over the current growing season (May-September) are not correlating with the year effect of RW (Fig. 6), unlike the mean temperature for September of current year (which is biologically not logical). However, the year effect of RD correlates with the mean temperature for June $\left(R^{2}=0.479\right)$, October mean temperature of the previous year (which is not either biologically logical) and the temperature sum over the current growing season $\left(R^{2}=0.486\right)$.

\section{Discussion and conclusions}

The main aim in this study was to investigate which variables (i.e. spacing, origin group and climatic factors) could explain the variability observed for RW and RD

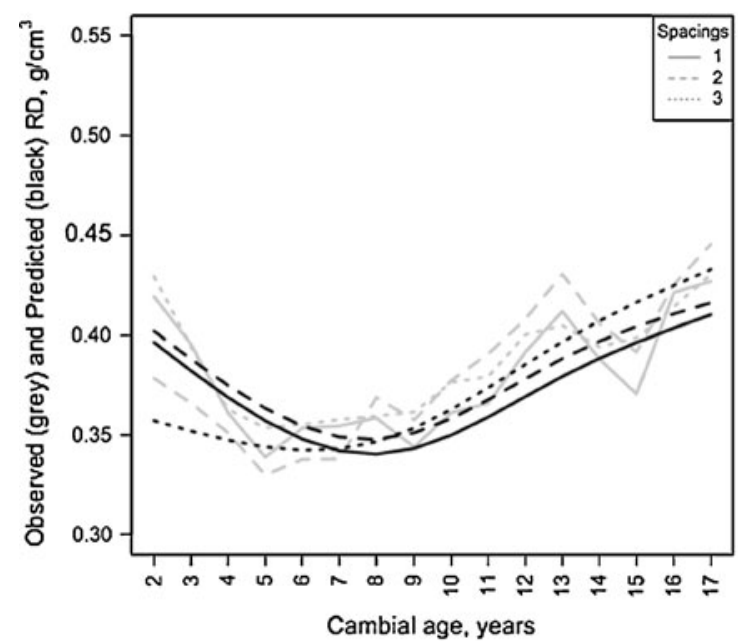

Spacing 2

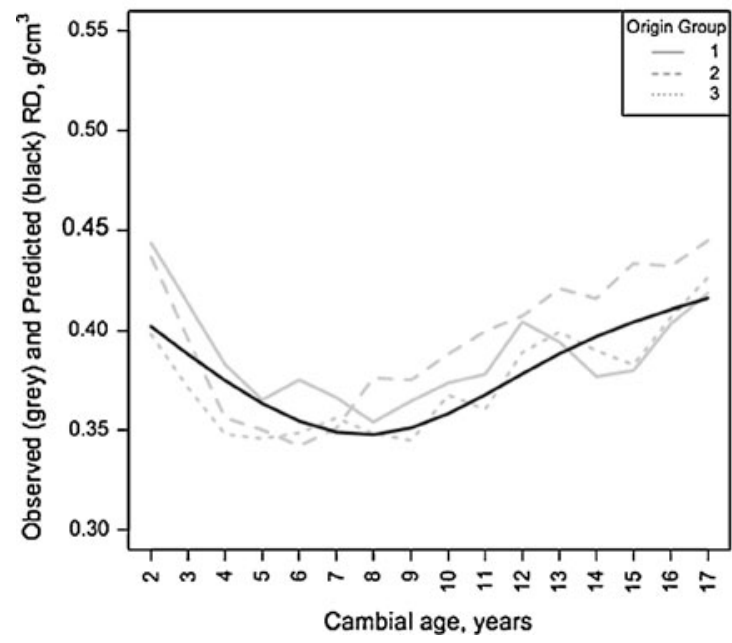

Fig. 4 Mean ring density (RD, g/ $\mathrm{cm}^{3}$ ) development from pith to bark for trees in each spacing as an average over all origin groups (from 1 to 3 , north to south) and for each origin group spacing by spacing development from pith to bark. No statistically significant differences were found for mean RW and Dt1 development in the early phase of stand development, regardless of initial spacing or origin group. However, the age dependency of RW decrease starts, on average, 2 years earlier (cambial age 5) in the narrowest spacing 3 , in which RW is smaller than in the two wider spacing 1 and 2. Differences also exist for the Dt1 between spacing 3 and spacing 1 and 2 , once the cambial age reaches 11 years.

The different OGs do not show significant differences for mean RW or Dt1, regardless of spacing. Similar to the mean RW, significant differences for mean RD development for different OGs and/or spacing treatments are not observed (except for a few single years). However, trees in the wider spacing seem to have, in general, slightly lower $\mathrm{RD}$ than in the narrower spacing, which is in line with previous findings for Scots pine (e.g. Persson et al. 1995).
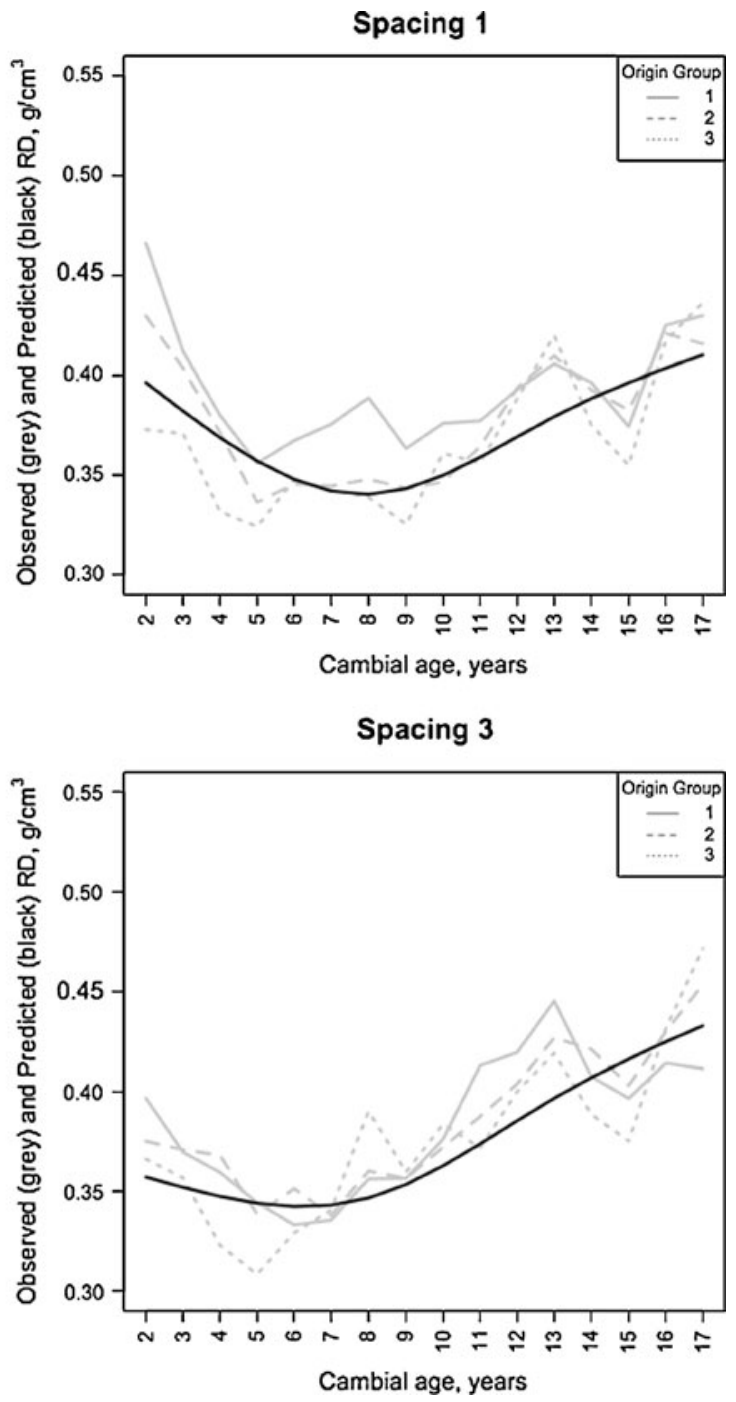

(from 1 to 3, widest to narrowest). Grey lines represent observed data and black lines predicted values 

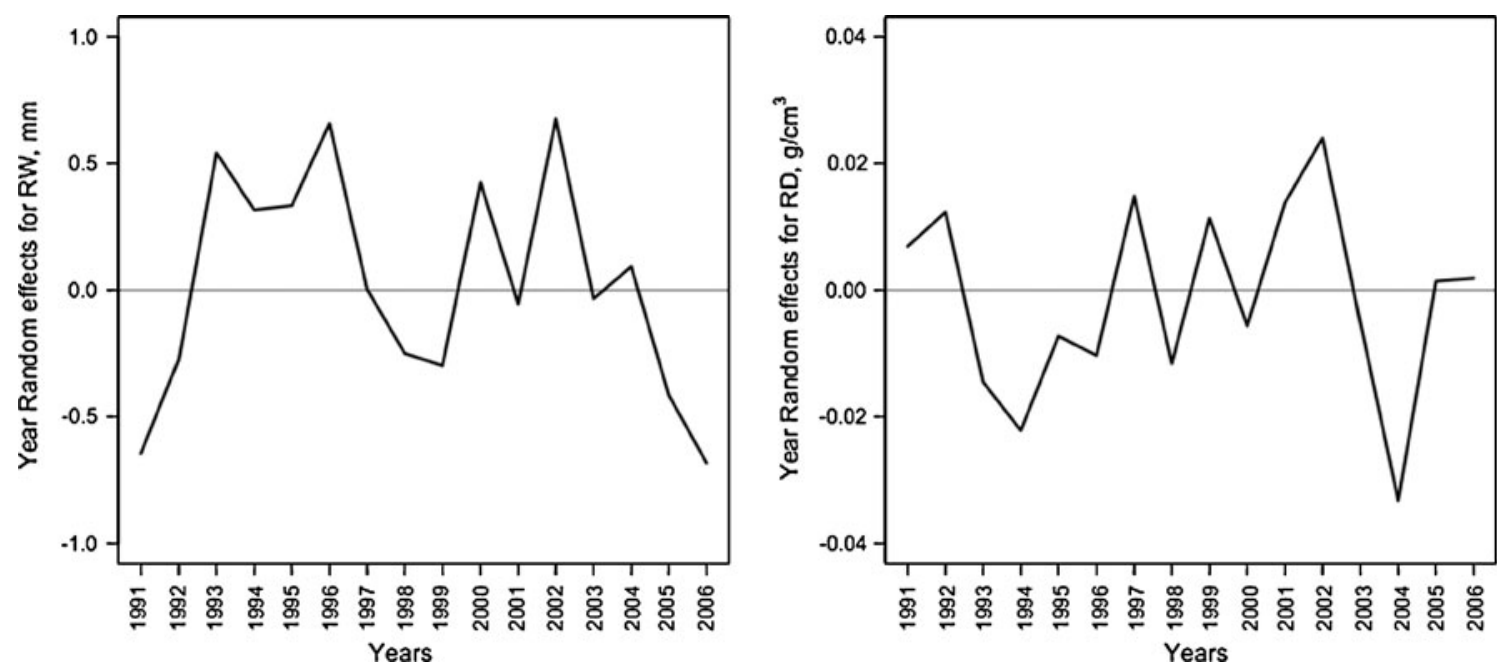

Fig. 5 Random year effects based on built models for ring width (RW, mm (left)) and for ring density (RD, g/ $\left.\mathrm{cm}^{3}(r i g h t)\right)$

The ranking between origin groups for the mean $\mathrm{RD}$ varies, however, depending on the cambial age considered. Thus, there is not a clear effect of OGs for the RD.

The annual development of RW can be best explained by the linear mixed model with explanatory variables of cambial age, spacing treatment and random "Tree" and "Year" effects. Whereas, the corresponding development of $\mathrm{RD}$ is best explained by origin group, cambial age, spacing treatment, and random "Tree" and "Year" effects. On the other hand, the random year effects for RW do not correlate well with any studied climatic factors during the growing season (e.g. with temperature sum during the growing season or June and July mean temperature). The observed significant correlation between the mean temperature for

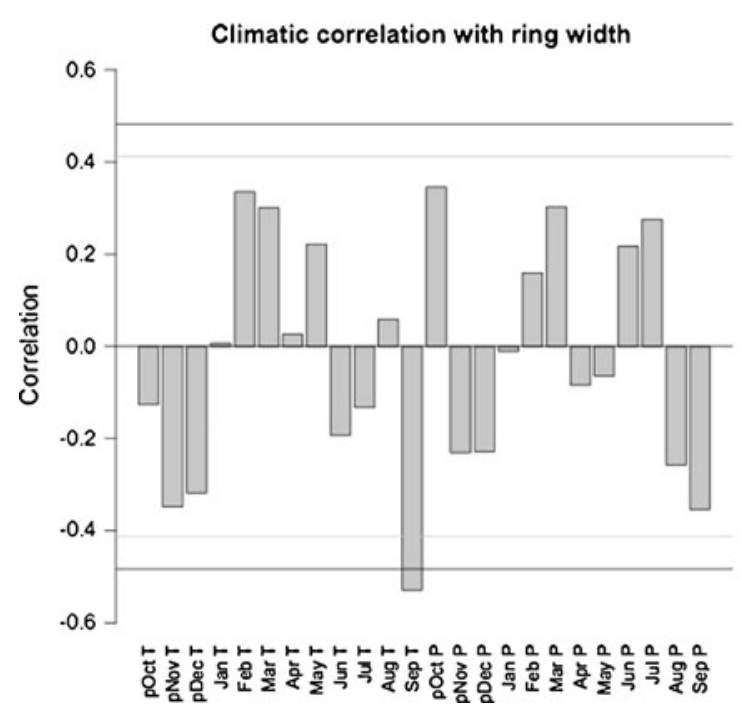

Fig. 6 Correlation of year effects for the ring width (left) and the ring density (right) with monthly average temperature $(\mathrm{T})$ and precipitation sum $(\mathrm{P})$ for the previous growing season (pOct-pDec) and the current
September of current year with RW (Fig. 6) does not make biological sense because in central Finland, in Scots pine most of the radial growth happens during June and July (see e.g. Henttonen et al. 2009).

On the other hand, the mean temperature for June of current year correlates significantly with $\mathrm{RD}$, as does the temperature sum over the growing season $(p<0.05)$. Additionally, observed significant correlation between the mean temperature for October in previous year with RD does not have to be real, as in Scots pine late wood formation and ring density dependent mainly on the prevailing temperature between July and August (e.g. Saikku 1975; Kellomäki 1979). However, it has also been suggested that for young Scots pine trees, some climatic

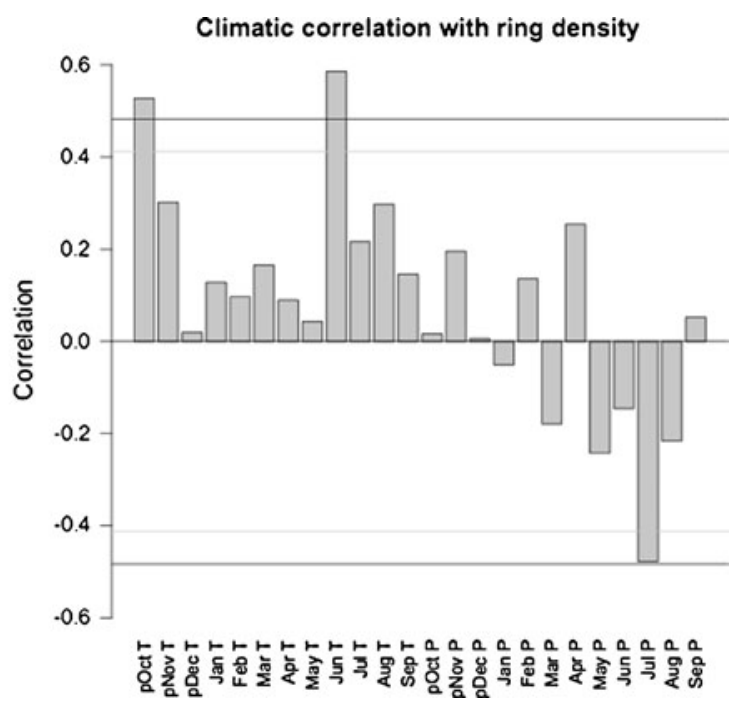

growing season (Jan-Sep) (black line shows statistically significant correlation, $p<0.05$ and grey line $p<0.10$ ) 
factors during the previous growing season may also affect RW and RD (Mikola 1950). In any case, it is possible that the relative short time series studied in this work and the fact that all trees were equally old affected our results (i.e. lack of statistically significant effects of climatic variables on the mean RW and RD). However, in 2002, both the mean RW and mean RD show a peak regardless of spacing and origin group, which may be related to a higher average temperature sum during the growing seasons of 2001 and 2002 than on average for the whole study period considered (see Fig. 1). In addition, May 2002 was the warmest month during all the years studied, inducing an earlier growth start.

In conclusion, this study revealed no significant differences for mean RW and RD development between different spacing and/or origin groups (southern, central and northern ones) in the early phase of stand development. But in general, both cambial age and spacing affected RW and RD development from pith to bark. The latter was also affected by the OG. However, the annual variation in RW could not be explained, e.g. by the temperature sum during the growing season or June and/or July mean temperature. But the mean temperature for current June and the temperature sum during the current growing season partly explained the annual variation in RD.

Unfortunately, the value of our findings is, at least in some degree, limited for practical forestry point of view, because Kanerva pine is not cultivated (at least yet) in practical forestry in Finland or elsewhere. However, despite of possible limitations of our work (limited number of genetic entries/ origin groups and spacing and relatively short length of time series), our findings on the effects of spacing on ring width and ring density development of young Scots pine trees could be taken as valuable contribution for the practical forest management point of view. This is because very wide annual rings are not desired in juvenile wood phase, as they have a negative effect on the strength properties of sawn timber.

Acknowledgements The authors would like to thank the Finnish Forest Research Institute (FFRI) for providing the study material. Moreover, Mr. Raimo Jaatinen from FFRI and Mr. Jarmo Pennala and Ms. Marja Kuskelin, from the University of Eastern Finland (formerly University of Joensuu until end of 2009), are thanked for harvesting the sample trees in our spacing trial. Mr. Jarmo Pennala is also thanked for assistance with X-ray measurements. Dr. David Gritten is thanked for the English revision of the manuscript. The support provided by the University of Eastern Finland, School of Forest Sciences, the Graduate School for Forest Sciences as well as the Finnish Forest Research Institute and the Finnish Meteorological Institute are gratefully acknowledged.

\section{References}

Antonova G-F, Stasova V-V (1993) Effects of environmental factors on wood formation in Scots pine stems. Trees 7:214-219
Bergsten U, Lindeberg J, Rindby A, Evans R (2001) Batch measurements of wood density on intact or prepared drill cores using $\mathrm{X}-$ ray microdensitometry. Wood Sci Technol 35:435-452

Fries A, Eriksson T (2006) Estimating genetic parameters for wood density of Scots pine (Pinus sylvestris L.). Silvae Genetica 55:84-92

Hannrup B, Ekberg I (1998) Age-age correlations for tracheid length and wood density in Pinus sylvestris. Can J For Res 28:13731379

Hannrup B, Ekberg I, Persson A (2000) Genetic correlations among wood, growth capacity and stem traits in Pinus silvestris. Scan J Forest Res 15:161-170

Harrell F-E (2001) Regression modeling strategies with applications to linear models, logistic regression, and survival analysis. Springer Series in Statistics. 568 p. ISBN: 978-0387-95232-1.

Henttonen HM (1984) The dependence of annual ring increases on some climatic factors. Acta For Fenn 186:1-38

Henttonen HM, Mäkinen H, Nöjd P (2009) Seasonal dynamics of the radial increment of Scots pine and Norway spruce in the southern and middle boreal zones in Finland. Can J For Res 39:606-618

Kanninen M, Hari P, Kellomäki S (1982) A dynamic model for above ground growth of dry matter production in a forest community. $\mathrm{J}$ Appl Ecol 19:465-476

Kellomäki S (1979) The effect of solar radiation and air temperature on basic density of Scots pine wood. Silva Fennica 13:304-315

Leikola M (1969) The influence of environmental factors on the diameter growth of forest trees. Auxanometric study. Acta For Fenn 92:1-144

Mielikäinen K, Timonen M, Nöjd P (1996) Männyn ja kuusen kasvuun vaihtelu Suomessa 1964-1993. Folia For 4:309-320

Miina J (2000) Dependence of tree-ring, earlywood and latewood indices of Scots pine and Norway spruce on climatic factors in eastern Finland. Ecol Model 132:259-273

Mikola P (1950) Puiden kasvun vaihtelusta ja niiden merkityksestä kasvututkimuksissa. Summary: on variations in tree growth and their significance to growth studies. Commun Inst For Fenn $38: 1-131$

Mörling T (2002) Evaluation of annual ring width and ring density development following fertilisation and thinning of Scots pine. Ann Forest Sci 59:29-40

Peltola H, Kilpeläinen A, Kellomäki S (2002) Diameter growth of Scots pine (Pinus sylvestris) trees grown at elevated temperature and carbon dioxide concentration under boreal conditions. Tree Physiol 22:963-972

Peltola H, Kilpeläinen A, Sauvala K, Räisänen T, Ikonen V-P (2007) Effects of early thinning regime and tree status on the radial growth and wood density of Scots pine. Silva Fennica 41:489505

Persson B, Persson A, Ståhl EG, Karlmats U (1995) Wood quality of Pinus sylvestris progenies at various spacings. Forest Ecol Manag 76:127-138

Pinheiro JC, Bates DM (2000) Mixed-effects models in S and SPLUS. Springer, New York

Saikku O (1975) The effect of fertilization on the basic density at Scots pine (Pinus sylvestris L.) A densiometric study on the $\mathrm{x}$-ray chart curves of wood. Commun Inst For Fenn 85.3

Salminen H, Jalkanen R (2004) Does current summer temperature contribute to the final shoot length on Pinus sylvestris? A case study at the northern conifer timberline. Dendrochronologia 21:79-84

Salminen H, Jalkanen R, Lindholm M (2009) Summer temperature affects the ratio of radial and height growth of Scots pine in northern Finland. Ann Forest Sci 66:810 
Shapiro SS, Wilk MB (1965) An analysis of variance test for normality (complete samples). Biometrika 52:591-611. doi:10.1093/biomet/52.3-4.591

Ståhl EG (1988) Transfer effect and variations in basic density and tracheid length of Pinus sylvestris L. populations. Studia Forestalia Suecica 180:15
Wilhelmsson L, Arlinger J, Spångberg K, Lundqvist S-O, Grahn T, Hedenberg Ö, Olsson L (2002) Models for predicting wood properties in stems of Picea abies and Pinus sylvestris in Sweden. Scand J Forest Res 17:330-350

Zobel BJ, Van Buijtenen JP (1989) Wood variation: its causes and control. Springer, Berlin, p 363 